\title{
Nutrient requirements of energy and protein for Holstein $\times$ Zebu bulls finished in feedlot
}

\author{
Requerimentos nutricionais de energia e proteína em bovinos \\ Holandês $\times$ Zebu não castrados terminados em confinamento
}

\author{
Polyana Pizzi Rotta ${ }^{1 *}$; Sebastião Campos Valadares Filho²; Edenio Detmann²; \\ Luiz Fernando Costa e Silva ${ }^{3}$; Faider Alberto Castaño Villadiego ${ }^{4}$; \\ Eusebio Manuel Galindo Burgoss; Flávia Adriane Sales Silva ${ }^{5}$
}

\begin{abstract}
The objective of this study was to estimate the nutritional requirements of energy and protein in crossbred (Holstein $\times$ Zebu) bulls. An experiment of comparative slaughter was conducted with 44 (24 months old) crossbred bulls of $338 \pm 39 \mathrm{~kg}$. Bulls were randomly separated as follows: four bulls to the control group, four bulls to the maintenance level group and 36 bulls were fed ad libitum. Corn silage (CS) and sugar cane in natura (SC) at 60 or $40 \%$ of dry matter (DM) of total diets were utilized in the diets. The bulls of the last group were randomly assigned to one of six different diets: 1) 60CS:40C(84 days); 2) 60CS:40C (42 days) and 40CS:60C (42 days); 3) 40CS:60C (84 days); 4) 60SC:40C (84 days); 5) 60SC:40C (42 days), and 40SC:60C (42 days), and 6) 40SC:60C (84 days). At the end of the experiment, bulls were slaughtered at Universidade Federal de Viçosa for estimation of the empty body weight. One sample located between the $9^{\text {th }}$ and the $11^{\text {th }}$ ribs of each bull was taken and completely dissected for estimation of the empty body composition using equations developed by BR-CORTE 2010. The data were analyzed as nonlinear models built by means of command NLIN of SAS (version 9.2), adjusted by the method of Gauss-Newton. For all the tests, 0.05 was utilized as critical level for probability of type I error. The net $\left(\mathrm{NE}_{\mathrm{m}}\right)$ and metabolizable $\left(\mathrm{ME}_{\mathrm{m}}\right)$ energy requirements for maintenance were 78.7 and $114.2 \mathrm{kcal} / \mathrm{EBW}^{0.75} /$ day, respectively. The equations obtained for $\mathrm{NE}_{\mathrm{g}}$ and $\mathrm{NP}_{\mathrm{g}}$ were: $\mathrm{NE}_{\mathrm{g}}$ $(\mathrm{Mcal} /$ day $)=0.0493 \times \mathrm{EBW}^{0.75} \times \mathrm{EBWG}^{1.0013}$ and $\mathrm{NP}_{\mathrm{g}}$ (g/day) $=279.19 \times \mathrm{EBWG}^{\mathrm{g}}-22.8691 \times \mathrm{RE}^{\mathrm{g}}$, respectively. The model obtained for the percentage of retained energy as protein $\left(\% \mathrm{RE}_{\mathrm{p}}\right)$ was $\% \mathrm{RE}_{\mathrm{p}}=$ $1.7202 \times(\mathrm{RE} / \mathrm{EBWG})^{-1.351}$.
\end{abstract}

Key words: Corn silage, deposition, efficiency, net energy, metabolizable energy, sugar cane

\section{Resumo}

Objetivou-se com este estudo estimar as exigências nutricionais de energia e proteína em bovinos cruzados (Holandês $\times$ Zebu). Um experimento de abate comparativo foi conduzido com 44 (24 meses) bovinos cruzados pesando $338 \pm 39 \mathrm{~kg}$. Os bovinos foram aleatoriamente separados como segue: quatro bovinos para o grupo referência, quatro bovinos para o grupo mantença e 36 bovinos alimentados $a d$

\footnotetext{
${ }^{1}$ Discente de Doutorado do Programa de Pós Graduação em Zootecnia, Universidade Federal de Viçosa, UFV, Viçosa, MG. E-mail: polyana.rotta@ufv.br

${ }^{2}$ Profs. da Universidade Federal de Viçosa, UFV, Viçosa, MG. E-mail: scvfilho@ufv.br; detmann@ufv.br

${ }^{3}$ Discente de Doutorado do Programa de Pós Graduação em Zootecnia, UFV, Viçosa, MG. E-mail: 1fcostasilva@yahoo.com.br

${ }^{4}$ Discente(s) de Doutorado do Programa de Pós Graduação em Medicina Veterinária, UFV, Viçosa, MG. E-mail: faideralberto. castanovilladiego@facebook.com; eusebio.galindo@facebook.com.br

${ }^{5}$ Discente de Graduação em Zootecnia, UFV, Viçosa, MG. E-mail: flavia.sales.908@facebook.com.br

* Author for correspondence
} 
libitum. Foram utilizadas a silagem de milho (SM) e a cana-de-açúcar in natura (CA) nas proporções de 60 ou $40 \%$ na base da matéria seca (MS) total das dietas. As seis dietas experimentais foram constituídas da seguinte forma: 1) 60 SM: 40\% de concentrado (C) durante 84 dias; 2) 60SM: 40C (42 dias) e 40SM:60C (42 dias); 3) 40SM:60C (84 dias); 4) 60CA:40C (84 dias); 5) 60CA:40C (42 dias) e 40CA:60C (42 dias) e 6) 40CA:60C (84 dias). Ao final do experimento, todos os animais foram abatidos para determinação do peso de corpo vazio (PCVZ). Uma amostra compreendida entre a $9^{\mathrm{a}} \mathrm{e}$ a $11^{a}$ costelas da meia carcaça esquerda foi retirada e completamente dissecada para a estimação da composição química do PCVZ utilizando as equações descritas no BR-CORTE em 2010. Os dados foram analisados como modelos não lineares elaborados por médias do comando NLIN do SAS (versão 9.2), ajustados pelo método de Gauss-Newton. Para todos os testes, 0.05 foi utilizado como nível crítico de probabilidade para o erro tipo I. As exigências de energia líquida $\left(E_{\mathrm{m}}\right)$ e metabolizável $\left(\mathrm{EM}_{\mathrm{m}}\right)$, para mantença foram de 78,7 e 114,2 kcal/PCVZ ${ }^{0,75} /$ dia, respectivamente. $\mathrm{A}_{\mathrm{m}}$ foi de 0,6891 . As equações obtidas para as exigências líquidas para ganho de energia $\left(\mathrm{EL}_{\mathrm{g}}\right)$ e proteína $\left(\mathrm{PL}_{\mathrm{g}}\right)$ foram: $\mathrm{EL}_{\mathrm{g}}(\mathrm{Mcal} / \mathrm{dia})$ $=0,0493 \times \mathrm{PCVZ}^{0,75} \times \mathrm{GPCVZ}^{1,0013}$ e PL $(\mathrm{g} / \mathrm{dia})=279,19 \times \mathrm{GPCVZ}-22,8691 \times \mathrm{ER}$, respectivamente. $A k_{\mathrm{g}}$ foi de 0,4634 . As eficiências de utilização da energia metabolizável para a deposição de proteína e gordura foram de 0,2048 e 0,8848 , respectivamente. O modelo obtido para a percentagem de energia retida na forma de proteína $\left(\% \mathrm{ER}_{\mathrm{p}}\right)$ foi: $\% \mathrm{ER}_{\mathrm{p}}=1,7202 \times(\mathrm{ER} / \mathrm{GPCVZ})^{-1,351}$.

Palavras-chave: Deposição, eficiência, energia líquida, energia metabolizável

\section{Introduction}

Since the 13th century, researchers have been inquired about the search for information on the utilization of energy by animals. Thus, over the years, models for studies and prediction of the energy and protein requirements of animals have been developed (FERREL; OLTJEN, 2008).

The higher operational cost of production in beef cattle is due to nutrition, so the accurate knowledge of the nutritional requirements of the animals, and the knowledge of the nutritional value of the feedstuffs, are essential for the formulation of adequate diets and the consequent increase in the productive, economic and environmental efficiency of the activity (GIONBELLI, 2010).

Most of the balancing of diets for beef cattle in Brazil was, until recently, performed based on information reported by international councils (AFRC, 1993; NRC, 2000). These councils utilize in it's database, animals with different characteristics from those raised in Brazil. Therefore, Valadares Filho et al. (2010) published the 2nd edition of the Brazilian Table of Nutritional Requirements of Zebu Cattle (BR-CORTE), whose database is based on animals with similar characteristics and conditions to those reared in Brazilian territory.
However, estimates of the nutritional requirements of energy and protein for crossbred Holstein $\times$ Zebu animals are scarce in the database from BR-CORTE. When taking it into account, in some regions of Brazil, the utilization of systems in which Holstein $\times$ Zebu animals are utilized for production of meat is significant, the nutritional requirements of these animals become necessary to optimize the production.

Therefore, the objective of this experiment was to estimate the nutritional requirements of energy and protein in crossbred feedlot Holstein $\times$ Zebu bulls.

\section{Material and Methods}

The experiment took place at the animal feedlot of the Department of Animal Science of Universidade Federal de Viçosa, MG, Brazil.

Forty-four crossbred Holstein $\times$ Zebu bulls at average age of 24 months and average body weight of $338 \pm 39 \mathrm{~kg}$ were utilized in the experiment, which designed as a completely randomized, with a total duration of 84 days, divided in four periods of 21 days.

Animals were confined in individual concretefloored pens, provided with concrete bunks and 
waterers, with a total are of $30 \mathrm{~m}^{2}$, of which $8 \mathrm{~m}^{2}$ were covered.

Bulls went through a 30-day period of adaptation to the experimental facilities and received a diet based on shredded elephant grass as roughage ad libitum, and $2 \mathrm{~kg}$ concentrate with $200 \mathrm{~g} / \mathrm{kg}$ crude protein daily. During this period, animals were identified and treated against ecto- and endoparasites. After this adaptation period, they were weighed at a 14 hours solid fasting and randomly distributed to three groups: reference $(n=4)$, maintenance $(n=4)$ and fed ad libitum $(\mathrm{n}=36)$.

Animals fed ad libitum were once again randomly distributed to six groups (six bulls in each one), which received the experimental diets. After this distribution, the animals were subjected to a 14day period of adaptation to the experimental diets, with gradual increase of the level of concentrate in the diet. In the first week $50 \%$ of the concentrate was given and in the second week $100 \%$ of the concentrate was given to the bulls.

The four bulls set to the reference group were slaughtered in the beginning of the experiment. Bulls of the maintenance group were fed 1.2\% of their body weight. Before the beginning of the experiment, the animals were weighed again at solid fasting of 14 hours and distributed to the following experimental diets (dry matter basis):

1) $60 \%$ corn silage $+40 \%$ concentrate (during 84 days);

2) $60 \%$ corn silage $+40 \%$ concentrate (first 42 days) and $40 \%$ corn silage $+60 \%$ concentrate (last 42 days);

3) $40 \%$ corn silage $+60 \%$ concentrate (during 84 days);

4) $60 \%$ sugarcane in natura $+40 \%$ concentrate (during 84 days);

5) $60 \%$ sugarcane in natura $+40 \%$ concentrate (first 42 days) and 40\% sugarcane in natura $+60 \%$ concentrate (last 42 days);
6) $40 \%$ sugarcane in natura $+60 \%$ concentrate (during 84 days).

Each one of the bulls fed at maintenance level was randomly subjected to one of the following diets:

1) $60 \%$ corn silage $+40 \%$ concentrate (during 84 days);

2) $40 \%$ de corn silage $+60 \%$ concentrate (during 84 days);

3) $60 \%$ de sugarcane in natura $+40 \%$ concentrate (during 84 days);

4) $40 \%$ de sugarcane in natura $+60 \%$ concentrate (during 84 days).

At the end of periods two and four, the animals were weighted after a solid fasting of 14 hours, for evaluation of the average daily gain.

The corn silage was collected from a trench-type silo one hour prior to its delivery to animals, and sugarcane (whole plant) was shredded daily before feeding. Corn silage and sugarcane had the dry matter (DM) content evaluated daily for adjustment of the amount of concentrate and urea + ammonium sulfate supplied to animals. The mixture of urea + ammonium sulfate (9:1) was utilized to elevate the contents of crude protein $(\mathrm{CP})$ of roughages to $120 \mathrm{~g} / \mathrm{kg}$. Dry matter was evaluated by using a conventional microwave oven, according to recommendations of the National Forage Testing Association (1993).

The brix degree of sugarcane was measured on the 10th day of each experimental period. Three samples of sugarcane were randomly collected and the brix degree was estimated using a manual refractometer. The average value observed for the brix degree of sugarcane during the experiment was $22 \pm 1$.

A single concentrate composed of $90.40 \%$ corn meal; $7.90 \%$ soybean meal; $0.85 \%$ mineral mixture and $0.85 \%$ common salt was supplied; its composition is shown in Table 1. 
Table 1. Chemical composition of feed used in experimental diets.

\begin{tabular}{lccccccc}
\hline \multirow{2}{*}{ Feed } & $\mathrm{DM}^{1}$ & $\mathrm{OM}^{2}$ & $\mathrm{CP}^{3}$ & $\mathrm{EE}^{4}$ & $\mathrm{NDFap}^{5}$ & $\mathrm{NFC}^{6}$ & $\mathrm{iNDF}^{7}$ \\
\cline { 2 - 7 } & & & $\mathrm{g} / \mathrm{kg} \mathrm{DM}$ & & & \\
\hline Corn silage & 300.80 & 947.10 & 65.70 & 32.44 & 515.70 & 333.30 & 140.20 \\
Sugar cane & 281.60 & 973.80 & 28.30 & 15.76 & 458.70 & 471.04 & 222.06 \\
Corn & 901.90 & 989.40 & 94.80 & 35.70 & 144.40 & 714.50 & 1.71 \\
Soybean meal & 875.00 & 951.80 & 528.00 & 14.80 & 124.20 & 284.80 & 0.64 \\
Mineral mix & 975.40 & 160.00 & 0 & 0 & 0 & 0 & 0 \\
Salt & 933.10 & 114.90 & 0 & 0 & 0 & 0 & 0 \\
Urea + ammonium sulfate & 950.60 & 984.90 & 2630.80 & 0 & 0 & 0 & 0 \\
\hline
\end{tabular}

${ }^{1} \mathrm{DM}=$ Dry matter; ${ }^{2}$ Organic matter; ${ }^{3} \mathrm{Crude}$ protein; ${ }^{4}$ Ether extract; ${ }^{5}$ Neutral detergent fiber corrected to ash and protein; ${ }^{6}$ Nonfibrous carbohydrates; ${ }^{7}$ Indigestible neutral detergent fiber; ${ }^{8}$ Mineral mixed composition $=266 \mathrm{~g} / \mathrm{kg}$ of calcium; $147 \mathrm{~g} / \mathrm{kg}$ of phosphorus; $7 \mathrm{~g} / \mathrm{kg}$ of magnesium; $3 \mathrm{~g} / \mathrm{kg}$ of potassium; $7 \mathrm{~g} / \mathrm{kg}$ of sulfur; $2 \mathrm{~g} / \mathrm{kg}$ of sodium; $118 \mathrm{mg} / \mathrm{kg}$ of chrome; 1,191 mg/kg of copper; $5,070 \mathrm{mg} / \mathrm{kg}$ of iron; 1,728 mg/kg of manganese; 4,198 mg/kg of zinc; and $136 \mathrm{mg} / \mathrm{kg}$ of cobalt.

Source: Elaboration of the authors.

Isoprotein diets (120 g/kg crude protein) according to Valadares Filho et al. (2010) were formulated for a gain of $1.20 \mathrm{~kg} /$ day, (Table 2).

Table 2. Proportions of feed in concentrate and diet and concentrate and diet composition in dry matter basis.

\begin{tabular}{lccccc}
\hline \multirow{2}{*}{ Items } & \multirow{2}{*}{ Concentrate } & \multicolumn{2}{c}{ Corn silage } & \multicolumn{2}{c}{ Sugar cane } \\
\cline { 2 - 5 } & & $60: 40$ & $40: 60$ & $60: 40$ & $40: 60$ \\
\cline { 2 - 5 } & \multicolumn{5}{c}{$\mathrm{g} / \mathrm{kg}$} \\
Roughage & - & $600^{1}$ & $400^{1}$ & $600^{2}$ & $400^{2}$ \\
Corn & 904.00 & 361.60 & 542.40 & 361.60 & 542.40 \\
Soybean meal & 79.00 & 31.60 & 47.40 & 31.60 & 47.40 \\
Mineral mix & 8.50 & 3.40 & 5.10 & 3.40 & 5.10 \\
Salt & 8.50 & 3.40 & 5.10 & 3.40 & 5.10 \\
\hline & \multicolumn{5}{c}{ Chemical composition $(\mathrm{g} / \mathrm{kg})$} \\
\hline Organic matter & 973.40 & 957.60 & 962.90 & 973.60 & 962.90 \\
Crude protein & 126.20 & 124.60 & 129.40 & 117.60 & 129.10 \\
Ether extract & 33.50 & 33.00 & 20.60 & 13.20 & 19.80 \\
Neutral detergent fiber ${ }^{3}$ & 140.30 & 366.60 & 295.50 & 324.10 & 262.50 \\
Non-fibrous carbohydrates & 673.40 & 453.55 & 530.83 & 552.80 & 574.24 \\
Indigestible NDF & 3.31 & 97.60 & 75.40 & 144.76 & 106.80 \\
\hline
\end{tabular}

$120.60 \mathrm{~g}$ of urea + ammonium sulfate $\mathrm{kg} / \mathrm{DM}$ of roughage intake; ${ }^{2} 34.87 \mathrm{~g}$ of urea + ammonium sulfate $\mathrm{kg} / \mathrm{DM}$ roughage intake , ${ }^{3}$ corrected to ash and protein

Source: Elaboration of the authors.

The roughage (corn silage or sugarcane) was supplied in full at $08 \mathrm{~h} 00$ along with the mixture of urea + ammonium sulfate and half of the daily quantity of concentrate. At first, urea + ammonium sulfate was incorporated to the roughage, and after, the concentrate was added. At $15 \mathrm{~h} 00$, the other half of the roughage was supplied to animals. The amounts of roughage, concentrate and urea + 
ammonium sulfate supplied, as well as refused feed, were recorded daily. The diet supplied to animals was adjusted to keep leftovers at around 5 to $10 \%$ on a natural matter basis, with water permanently at their disposal.

Roughages and leftovers from each animal were sampled daily and subsequently conditioned in freezer $\left(-20^{\circ} \mathrm{C}\right)$. A composite sample of corn silage, sugarcane and composite samples of the leftovers from each animals were sent to drying in forcedventilation oven $\left(55^{\circ} \mathrm{C}\right)$ and ground in knife mill (1 and $2 \mathrm{~mm}$ ) weekly for the periods in which digestibility trials were conducted.

Afterwards, the total DM of these samples was evaluated according to National Forage Testing Association (1993). Based on the DM content of the leftovers from each animal, or on the amount of DM from the corn silage and sugarcane supplied, composite samples were made for each three weeks, totaling four samples of leftovers and roughages.

The ingredients which composed the concentrate were sampled on the days of its mixing. During each experimental period ( 21 days), two mixing of the ingredients were performed.

For the evaluation of total digestibility coefficients, the feces from all animals were collected at a specific time during the last three days of periods two and four. Rectal collections were performed at $6 \mathrm{~h} 00,12 \mathrm{~h} 00$ and $18 \mathrm{~h} 00$ of days one, two and three, respectively. Samples of feces were dried in forced-ventilation oven $\left(55^{\circ} \mathrm{C}\right)$ for 72 hours then ground in knife mill to 1 and $2 \mathrm{~mm}$. A composite sample was obtained per collection period for each animal.

Samples of corn silage, sugarcane, ingredients of the concentrate, refused feed and feces were quantified as for the contents of DM, mineral matter (MM), total nitrogen (TN), and ether extract (EE), according to Silva and Queiroz (2002). Crude protein $(\mathrm{CP})$ was obtained by the product between total nitrogen and factor 6.25. The content of neutral detergent fiber (NDF) was obtained according to
Mertens et al. (2002). In the analysis of soybean meal, sodium sulfite was added (UNDERSANDER; MERTENS; THIEX, 1993) to reduce retention of the protein content. The Ankom ${ }^{\circledR}$ system was utilized for evaluations of NDF, by adding thermostable $\alpha$-amylase. Non-woven fabric $\left(100 \mathrm{~g} / \mathrm{m}^{2}\right)$ filtering bags were utilized for the extractions. The NDF content was corrected for ash and crude protein in all samples.

Non-fibrous carbohydrates (NFC) were calculated as proposed by Detmann and Valadares Filho at al. (2010), in which $\mathrm{NFC}=1000-[(\mathrm{g} / \mathrm{kg}$ $\mathrm{CP}-\mathrm{g} / \mathrm{kg} \mathrm{CP}$ derived from urea $+\mathrm{g} / \mathrm{kg}$ urea $)+\mathrm{g} /$ $\mathrm{kg} \mathrm{NDF}$ ap $+\mathrm{g} / \mathrm{kg} \mathrm{EE}+\mathrm{g} / \mathrm{kg} \mathrm{MM}]$. The contents of total digestible nutrients (TDN) of the diets were estimated by $\mathrm{TDN}=\mathrm{DCP}+2.25 \times \mathrm{DEE}+\mathrm{DNDF}$ + DNFC (NRC, 2001). Digestible energy (DE) was obtained from the digestible nutrients multiplied by its respective energy values, as described by the NRC (2001), whereas the concentration of metabolizable energy (ME) was considered $82 \%$ of the DE (COELHO DA SILVA; LEÃO, 1979).

Samples of leftovers, feed and feces for periods two and four were analyzed as for the content of indigestible neutral detergent fiber (iNDF). The samples were incubated in the rumen for 288 hours according to Valente et al. (2011) in F57 Ankom $^{\circledR}$ bags. After the incubation period, the determination of the iDNF was done through the treatment of samples with neutral detergent.

At the end of the 84 days of experiment, all animals were slaughtered in experimental abattoir of Universidade Federal de Viçosa. Nine animals were slaughtered per day, randomly selected for each day of slaughter.

Before slaughter, animals were subjected to a solids-fast for 16 hours. The slaughter was performed via stunning and section of the jugular, followed by washing of the gastrointestinal tract (rumen, reticulum, omasum, abomasums and small and large intestines). The weights of heart, lungs, liver, spleen, kidneys, internal fat, industrial meat, 
mesentery, tail and trimmings (trachea, esophagus and reproductive system), along with those of the washed gastrointestinal tract, were summed with the other parts of the body (carcass, head, hide, feet and blood) for quantification of the empty body weight (EBW).

After slaughter, the carcass of each animal was separated in two half-carcasses, which were weighed, and then chilled $\left(4{ }^{\circ} \mathrm{C} ; 18\right.$ hours). After this time, half-carcasses were removed from the cold chamber for cutting and samples from the left carcass were taken from section between the 9th and the 11th ribs, according to recommendations of Hankins and Howe (1946).

The section comprehended between the 9th and the 11th ribs was divided in muscle, fat and bones; afterwards, each part was individually weighed. Muscle and fat were homogenized and ground. After grinding, a homogeneous sample was removed, thus constituting a single sample of muscle + fat. One homogeneous sample of bones was also taken and placed on aluminum trays to be lyophilized for evaluation of fat dry matter (FDM) content.

Samples of muscle + fat and bones were lyophilized during 72 hours using standard conditions and partially defatted through successive washings with petroleum ether in Soxhlet extractor, for evaluation of the partially defatted dry matter (PDDM). Next, its were ground in a ball mill for subsequent laboratory analyses. The fat removed at the partial extraction was calculated through the difference between FDM and PDDM, whose result was added to that obtained for residual ether extract in the PDDM, for quantification of the total fat content.

Samples of each animal component were evaluated for the contents DM, MM, TN, and EE, according to Silva and Queiroz (2002). CP was obtained by the product between total nitrogen and the factor 6.25 .

The chemical composition of the empty body was estimated by the equations proposed by Marcondes et al. (2010), published on BR-CORTE, described in Table 3.

Table 3. Equations used to estimate the chemical composition of the empty body weight in crossbred bulls.

\begin{tabular}{lc}
\hline \multirow{2}{*}{ Itens } & Equations \\
\cline { 2 - 2 } & Chemical composition of empty body weight \\
\hline Crude protein & $\mathrm{CPBE}(\%)=10.78+0.47 \times \mathrm{PB}_{\mathrm{Sec}}-0.21 \times \mathrm{VF}$ \\
Ether extract & $\mathrm{EEBE}(\%)=2.75+0.33 \times \mathrm{EE}_{\mathrm{Sec}}+1.80 \times \mathrm{VF}$ \\
\hline
\end{tabular}

$\mathrm{CP}_{\mathrm{Sec}}$ : Crude protein in the section between the 9-11th ribs; $\mathrm{EE}_{\mathrm{Sec}}$ : Ether extract in the section between the 9-11th ribs; VF: visceral fat percentage (renal, pelvic, cardiac and mesentery in the empty body weight); OV: organs and viscera percentages; $\mathrm{W}_{\mathrm{Sec}}: \mathrm{water}$ in the section between the 9-11 ${ }^{\text {th }}$ ribs; CPBE: CP in the body empty; EECZ: EE in the body empty

Source: Marcondes et al. (2010).

The evaluation of the body energy was obtained from the body contents of protein and fat and its respective caloric equivalents, according to the equation established by the AFRC (1980):

$$
\mathrm{EC}=5.6405 \mathrm{X}+9.3929 \mathrm{Y},
$$

in which $\mathrm{EC}=$ energy content (Mcal); $\mathrm{X}=$ body protein $(\mathrm{kg}) ; \mathrm{Y}=$ body fat $(\mathrm{kg})$.
For the conversion of body weight (BW) into $\mathrm{EBW}$, the relations between EBW and BW of animals kept in the experiment were calculated. For the conversion of empty body weight gain (EBWG) into body weight gain (BWG), the relations between them were calculated, and then utilized for conversion of the requirements for EBW gain into requirements for $\mathrm{BW}$. 
A regression equation was fitted between retained energy (RE), metabolic EBW $\left(\mathrm{kg}^{0.75}\right)$ and EBWG (day), for animals under maintenance and performance, by utilizing the following model:

$$
\mathrm{RE}=\mathrm{a} \times \mathrm{EBW}^{0.75} \times \mathrm{EBWG}^{\mathrm{b}}
$$

in which $\mathrm{RE}=$ retained energy $\left(\mathrm{Mcal} / \mathrm{EBW}^{0.75} /\right.$ day), $\mathrm{EBW}^{0.75}=$ metabolic empty body weight $\left(\mathrm{kg}^{0.75}\right), \mathrm{EBWG}=$ empty body weight gain $(\mathrm{kg} /$ day $)$.

The proportion of energy retained in the form of protein $\left(\% \mathrm{RE}_{\mathrm{p}}\right)$ was estimated according to the model suggested by Marcondes et al. (2010):

$$
\% \mathrm{RE}_{\mathrm{p}}=\beta_{0}+(\mathrm{RE} / \mathrm{EBWG})^{\beta 1}
$$

in which $\% \mathrm{RE}_{\mathrm{p}}=$ percentage of energy retained in the form of protein, $\mathrm{RE}=$ retained energy (Mcal/ day), $\mathrm{EBWG}=$ empty body weight gain $(\mathrm{kg} /$ day $)$ and $\beta_{0}$ and $\beta_{1}=$ regression parameters.

To estimate the requirements of energy for maintenance, the exponential method was utilized as recommended by Tedeschi et al. (2002). Thus, the requirement of net energy for maintenance $\left(\mathrm{NE}_{\mathrm{m}}, \mathrm{Mcal} / \mathrm{EBW}^{0.75} /\right.$ day) was calculated from the intercept $\left(\beta_{0}\right)$ of the exponential regression between BW and MEI, through the following model:

$$
\mathrm{HP}=\beta_{0} \times \mathrm{e}^{(\beta 1 \times \mathrm{MEI})},
$$

in which $\mathrm{HP}=$ heat production $\left(\mathrm{Mcal} / \mathrm{EBW}^{0.75} /\right.$ day), $\mathrm{MEI}=$ metabolizable energy intake (Mcal/ $\mathrm{EBW}^{0.75} /$ day), $\beta_{0}$ and $\beta_{1}=$ regression parameters and $\mathrm{e}=$ Euler number (3.718281).

To estimate the requirement of metabolizable energy for maintenance $\left(\mathrm{ME}_{\mathrm{m}}, \mathrm{Mcal} / \mathrm{EBW}^{0.75}\right.$ / day), the iterative method was utilized; $\mathrm{ME}_{\mathrm{m}}$ was considered the MEI value at the moment MEI equals to BW.

From the ratio between requirements of net and metabolizable energy for maintenance, the efficiency of utilization of metabolizable energy for maintenance was calculated $\left(\mathrm{k}_{\mathrm{m}}\right)$.

For the calculation of the partial use efficiencies of metabolizable energy for synthesis of protein and fat, the following model was fitted:

$$
\mathrm{MEI}=\mathrm{ME}_{\mathrm{m}}+\beta_{1} \times \Delta_{\text {prot }}+\beta_{2} \times \Delta_{\text {fat }},
$$

in which MEI is the total daily intake of metabolizable energy (Mcal/EBW $\left.{ }^{0.75}\right), \Delta_{\text {prot }}$ and $\Delta_{\text {fat }}$ are the variations of body energy in function of the protein and fat $\left(\mathrm{Mcal} / \mathrm{EBW}^{0.75}\right)$, respectively, and $\beta_{1}$ and $\beta_{2}$ are the coefficients of multiple regression.

The inverse of coefficients $\beta_{1}$ and $\beta_{2}$ account for the efficiencies of deposition of energy in the form of protein and fat $\left(\mathrm{k}_{\mathrm{prot}}\right.$ and $\left.\mathrm{k}_{\mathrm{fat}}\right)$, respectively.

For the calculation of the requirements of metabolizable protein for maintenance $\left(\mathrm{MP}_{\mathrm{m}}\right)$, the relation between metabolizable protein intake and average daily gain (ADG) was considered, in which $\mathrm{MP}_{\mathrm{m}}$ was the point at which the animal would have zero average daily gain.

For the calculation of net requirements of protein for weight gain, the model involving EBWG and the concentration of energy in the gain was fitted; animals under performance and maintenance were utilized:

$$
\mathrm{RP}=\beta_{1} \times \mathrm{EBWG}+\beta_{2} \times \mathrm{RE},
$$

in which $\mathrm{RP}=$ retained protein (g/day), EBWG = empty body weight gain $(\mathrm{kg} /$ day $), \mathrm{RE}=$ retained energy (Mcal/day) and $\beta_{1}$ and $\beta_{2}=$ regression parameters.

The estimate of requirement of metabolizable protein for gain $\left(\mathrm{MP}_{\mathrm{g}}\right.$ ) was obtained by dividing the net requirements of protein for gain by the utilization efficiency of the metabolizable protein for gain (k), according to equation proposed by Valadares Filho et al. (2010):

$$
\mathrm{k}(\%)=84.665-0.1179 \times \mathrm{eqEBW},
$$

in which eqEBW is the equivalent empty body weight, for body weights at fasting inferior to 350 $\mathrm{kg}$ and constant value of $46.9 \%$ for superior weights.

The data were analyzed as nonlinear models built by means of command NLIN of SAS (version 9.2), adjusted by the method of Gauss-Newton. For 
all the tests, 0.05 was utilized as critical level for probability of type I error.

\section{Results and Discussion}

The average ratio between EBW and BW was 0.8834 , which is close to those observed by BRCORTE (VALADARES FILHO et al., 2010) and in NRC (2000), which are 0.895 and 0.891, respectively. According to the NRC (2000), this ratio can vary from 0.85 to 0.95 .

For the conversion of requirements for EBW gain (EBWG) into requirements of body weight average daily gain (ADG), the mean ratio between EBWG and ADG was 1.0511. The NRC (2000) and Valadares Filho et al. (2010) presented EBWG/ BWG ratios of 0.951 and 0.936 , respectively. These values are 10.53 and $12.29 \%$ lower than the ones found in this study, respectively. The highest value observed in this study may be due to the utilization of animals which reached a high weight $(489.25 \mathrm{~kg})$ at the end of the experiment.

Relating the daily heat production (HP) with the metabolizable energy intake (MEI), expressed in $\mathrm{Mcal} / \mathrm{EBW}^{0.75}$, the following equation was obtained: $\mathrm{HP}=0.0787 \times \mathrm{e}^{(3.2611 \times \mathrm{MEI})}$. Thus, the net energy for maintenance value $\left(\mathrm{NE}_{\mathrm{m}}\right)$ obtained for crossbred Holstein $\times$ Zebu bulls was $78.7 \mathrm{kcal} / \mathrm{EBW}^{0.75} /$ day. Valadares Filho et al. (2010) suggested a value of $74.2 \mathrm{kcal} / \mathrm{EBW}^{0.75} /$ day. Chizzotti, Tedeschi and Valadares Filho (2008), in a study involving the analysis of data from 389 Nellore or crossbred (Bos taurus $\times$ Bos indicus) animals, estimated that the requirement for maintenance would be $75 \mathrm{kcal} /$ $\mathrm{EBW}^{0.75} /$ day. Thus, the value observed in this study is close to those observed by the authors previously mentioned.

The requirement of metabolizable energy for maintenance $\left(\mathrm{ME}_{\mathrm{m}}\right)$ was of $114.2 \mathrm{kcal} /$ day, which is obtained when HP equals to MEI.

The equation obtained for the body energy content (EC) in function of $\mathrm{EBW}$ was $\mathrm{EC}=0.3498 \pm 0.1678$ $\times \mathrm{EBW}^{1.3582 \pm 0.0792}$. As the EBW increases, there is increase in the concentration of energy in the animal due to the increase of body fat. The requirements of net energy (RE) per kg of EBWG can be calculated from the derivative of the equation: $\mathrm{RE}=0.4751$ $\times \mathrm{EBW}^{0.3582}$, in which RE is the requirement of net energy for gain (Mcal/kg EBWG) and the EBW is the empty body weight. The data obtained in this equation can only be considered for the animals of this experiment.

To estimate the requirements of energy for any range of weight and weight gain, the following equation was obtained: $\mathrm{NE}_{\mathrm{g}}=0.0493 \times \mathrm{EBW}^{0.75}$ $\times \mathrm{EBWG}^{1.0013}$, in which $\mathrm{NE}_{\mathrm{g}}$ is the requirement of net energy for gain (Mcal/day) and EBWG is the empty body weight gain ( $\mathrm{kg} /$ day). The intercept of the equation obtained is close to that suggested by Valadares Filho et al. (2010) for bulls, whose value was 0.053 . This demonstrates that the data generated by this experiment is agree with the data described in the national literature for non-castrate crossbred animals.

The main nutritional requirement systems (AFRC, 1993; NRC, 2000; CSIRO, 2007) separate the utilization efficiency of metabolizable energy into utilization efficiency of energy for maintenance $\left(\mathrm{k}_{\mathrm{m}}\right)$ and utilization efficiency of energy for gain $\left(\mathrm{k}_{\mathrm{g}}\right)$.

Dividing the $\mathrm{NE}_{\mathrm{m}}$ by $\mathrm{ME}_{\mathrm{m}}$, it obtains the $\mathrm{k}_{\mathrm{m}}$ value of 0.6891 . The $\mathrm{k}_{\mathrm{m}}$ values reported by Valadares Filho, Paulino and Magalhães (2006) and Chizzotti, Tedeschi and Filho (2008) were 0.63 and 0.67 , respectively. Thus, the value estimated in this study is close to those observed in the literature (VALADARES FILHO; PAULINO; MAGALHÃES, 2006; CHIZZOTTI; TEDESCHI; VALADARES FILHO, 2008).

Some factors can alter the $\mathrm{k}_{\mathrm{m}}$, e.g., the level of dietary fiber, the level of consumption of metabolizable energy, the proportion of absorbed fatty acids, the protein turnover (GARRETT, 1980). CSIRO (2007) reported that other factors 
such as sex, breed, age and environment could also affect $\mathrm{k}_{\mathrm{m}}$.

Marcondes et al. (2010) studied the effect of several factors on the $\mathrm{k}_{\mathrm{m}}$ and concluded that the partial use efficiency of the metabolizable energy for gain $\left(\mathrm{k}_{\mathrm{g}}\right)$ and the empty body weight gain (EBWG) could be the reason for alterations in $\mathrm{k}_{\mathrm{m}}$. It suggests that the requirements for maintenance are affected by animals performance. The model recommended for crossbred cattle by Marcondes et al. (2010) is $\mathrm{k}_{\mathrm{m}}$ $=0.513+0.173 \times \mathrm{k}_{\mathrm{g}}+0.073 \times$ EBWG, in which $\mathrm{k}_{\mathrm{m}}$ is the utilization efficiency of metabolizable energy for maintenance, $\mathrm{k}_{\mathrm{g}}$ is the utilization efficiency of metabolizable energy for gain and EBWG is the empty body weight gain, in $\mathrm{kg} /$ day.

Utilizing the equation proposed by Marcondes et al. (2010), the mean value for $\mathrm{k}_{\mathrm{m}}$ obtained for this experiment would be 0.66 . This value is close to that obtained by the division of $\mathrm{NE}_{\mathrm{m}}$ by $\mathrm{ME}_{\mathrm{m}}(0.68)$. However, the utilization of the $\mathrm{k}_{\mathrm{m}}$ variable becomes important, for when low-digestibility feedstuffs are utilized, the ME may present problems to estimate $\mathrm{k}_{\mathrm{m}}$ (JOHNSON; LARSON; JAROSZ, 1977).

To convert the requirements of net energy into requirements of metabolizable energy for gain, it is necessary to know the utilization efficiency of the metabolizable energy for weight gain $\left(\mathrm{k}_{\mathrm{g}}\right)$. Valadares Filho et al. (2010) affirmed that this efficiency can be estimated as the slope coefficient of the regression of RE in function of MEI (Figure 1).

Gionbelli (2010) utilized the same procedure and obtained $\mathrm{k}_{\mathrm{g}}$ value of 0.38 . This value is below the one found in this experiment, which was 0.4634 . Costa e Silva (2011), utilizing the same procedure, obtained inferior value ( 0.3325$)$ to that observed by Gionbelli (2010) and the one of this experiment.

In most of the studies conducted in Brazil, static values have been estimated for $\mathrm{k}_{\mathrm{g}}$. However, the efficiency with which energy is retained in the body $\left(\mathrm{k}_{\mathrm{g}}\right)$ depends on the proportions of energy retained in the form of protein and fat. Because the efficiency of deposition of fat is superior to that of protein and the proportion of protein and fat are variable, there is the need to obtain a $\mathrm{k}_{\mathrm{g}}$ also variable.

Figure 1. Retained energy (Mcal/EBW ${ }^{0.75} /$ day) in function of the metabolizable energy intake (Mcal/PCVZ ${ }^{0.75} /$ day) in crossbred bulls.

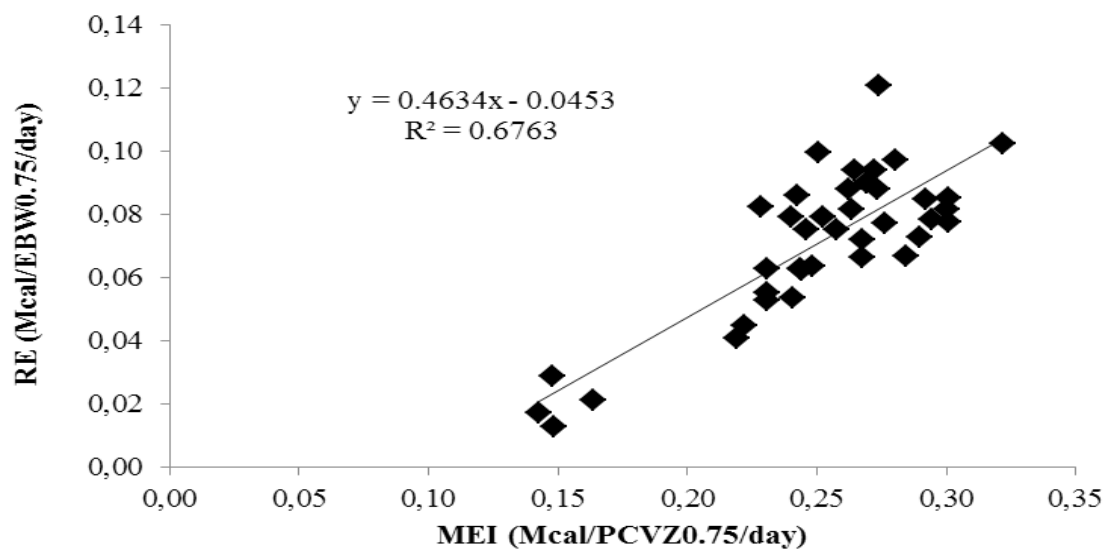

Source: Elaboration of the authors.

For the calculation of the partial use efficiencies of metabolizable energy for the synthesis of fat and protein, the following equation was obtained:
MEI $=114.2+4.88 \times \Delta_{\text {prot }}+1.13 \times \Delta_{\text {fat }}$, in which MEI is the daily metabolizable energy intake for maintenance $\left(\mathrm{Mcal} / \mathrm{EBW}^{0.75}\right)$ and $\Delta_{\text {prot }}$ and $\Delta_{\text {fat }}$ are 
variations of body energy in function of protein and fat $\left(\mathrm{Mcal} / \mathrm{EBW}^{0.75}\right)$.

From this model, the efficiencies of deposition of energy in the form of protein $\left(\mathrm{k}_{\mathrm{p}}\right)$ and fat $\left(\mathrm{k}_{\mathrm{f}}\right)$ were calculated. Thus, $\mathrm{k}_{\mathrm{p}}$ was equal to 0.2048 , and $\mathrm{k}_{\mathrm{f}}$, to 0.8848. Chizzotti, Tedeschi and Valadares Filho (2008), evaluating 16 experiments with 369 animals, obtained $\mathrm{k}_{\mathrm{p}}$ of 0.35 and $\mathrm{k}_{\mathrm{f}}$ of 0.79 . Gionbelli (2010) obtained $\mathrm{k}_{\mathrm{p}}$ of 0.25 and $\mathrm{k}_{\mathrm{f}}$ of 0.83 . The values observed for $\mathrm{k}_{\mathrm{p}}$ and $\mathrm{k}_{\mathrm{f}}$ by Costa e Silva (2011) were 0.18 and 0.71 , respectively.

The proportion of energy retained in the form of protein $\left(\% \mathrm{RE}_{\mathrm{p}}\right)$ was estimated according to the potential model proposed by Marcondes et al. (2010). The model obtained was $\% \mathrm{RE}_{\mathrm{p}}=3.0089 \times$ $(\mathrm{RE} / \mathrm{EBWG})^{-1.5061}$, in which $\% \mathrm{RE}_{\mathrm{p}}$ is the retained energy in the form of protein, $\mathrm{RE}$ is the retained energy, in Mcal/day, and EBWG is the empty body weight gain, in $\mathrm{kg} /$ day.

The $\% \mathrm{RE}_{\mathrm{p}}$ can be utilized in the conversion of net energy into metabolizable energy for being directly correlated to the utilization efficiency of metabolizable energy for gain (WILLIAMS; JENKINS, 2003; TEDESCHI; FOX; GUIROY, 2004). Marcondes et al. (2010) utilized a database from 752 animals raised under Brazilian conditions and did not observe differences between sex classes or between Nellore and crossbred animals for the $\% \mathrm{RE}_{\mathrm{p}}$, which was equal to $\% \mathrm{RE}_{\mathrm{p}}=1.140 \times(\mathrm{RE} /$ EBWG) $)^{-1.137}$.

Marcondes et al. (2010) suggested the calculation of $\mathrm{kg}$ in function of the $\mathrm{RE}_{\mathrm{p}}$, utilizing the equation: $\mathrm{k}_{\mathrm{g}}=0.327 /\left[0.539+\left(\% \mathrm{RE}_{\mathrm{p}} / 100\right)\right]$. Therefore, the utilization of this model, which considers a $\mathrm{k}_{\mathrm{g}}$ variable, seems to have more applicability, once there is the combination of the efficiency with the composition of gain.

In this study, the value of 2.72 was observed for the requirement of metabolizable protein for maintenance. This value was obtained by the division of the intercept (218.77) of the regression equation of the metabolizable energy intake $(\mathrm{g} /$ day) in function of the weight gain $(\mathrm{kg} / \mathrm{day})$ of the animals, by their metabolic live weight $(80.36)$ (Figure 2).

Figure 2. Relation between the metabolizable intake protein (g/day) and the average daily gain $(\mathrm{kg} / \mathrm{day})$ in crossbred bulls.

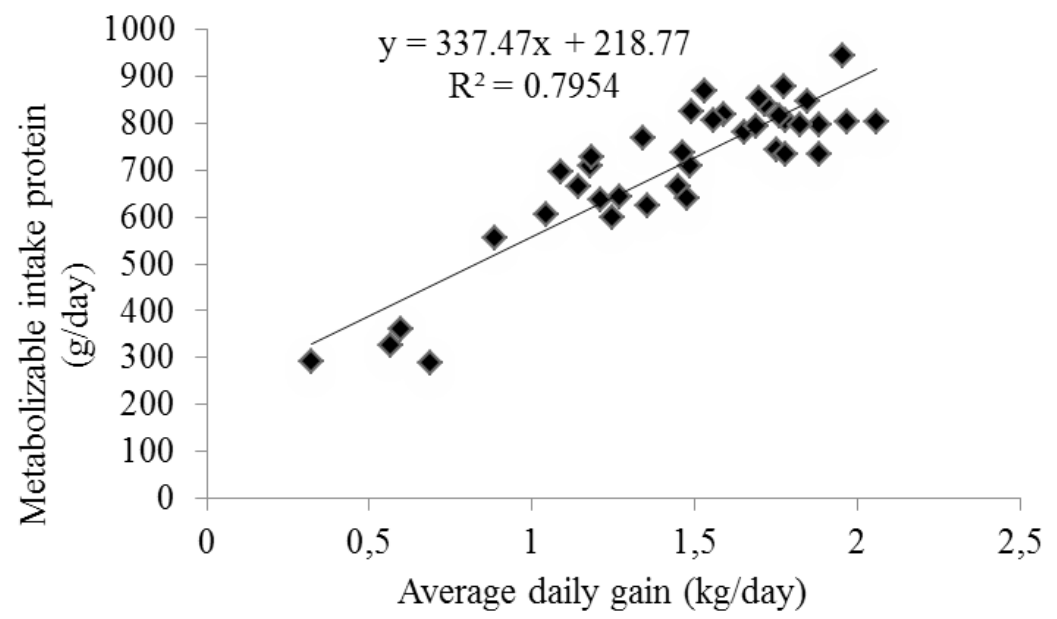

Source: Elaboration of the authors.

The equation obtained to describe the content of body crude protein $(\mathrm{BCP})$ in function of EBW was $\mathrm{BCP}=1.6100 \times \mathrm{EBW}^{0.6575}$, in which $\mathrm{BCP}$ is the body content of crude protein, in $\mathrm{kg}$, and EBW is 
the empty body weight, in $\mathrm{kg}$.

The net requirements of protein (PR), for one $\mathrm{kg}$ of gain of empty body weight, were estimated by the derivative of the following equation: $\mathrm{PR}=1.0586$ $\times \mathrm{EBW}^{-0.3425}$, in which $\mathrm{PR}$ is the net requirement of protein for gain, expressed in grams per $\mathrm{kg}$ of EBWG.

As the EBW of animals increases, there is a decrease in PR, represented by the negative exponent linked to EBW, resulting in lower gain of protein per $\mathrm{kg}$ of EBWG. With an increase in weight, there is reduction in the deposition of muscle tissue and an increase in the deposition of fat tissue for the body reserves.

The net requirements of protein $\left(\mathrm{NP}_{\mathrm{g}}\right)$ for any range of weight gain were estimated from a model involving the EBWG and the concentration of energy in gain: $\mathrm{NP}_{\mathrm{g}}=279.19 \times \mathrm{EBWG}-22.87 \times$ $\mathrm{RE}$, in which $\mathrm{NP}_{\mathrm{g}}$ is the net requirement of protein, in $\mathrm{g} /$ day, EBWG is the empty body weight gain, in $\mathrm{kg} /$ day, and RE is the retained energy, in Mcal/ day. The equation recommended by BR-CORTE (VALADARES FILHO et al., 2010) to estimate the net requirements of protein is: $\mathrm{PR}=238.79 \times$ EBWG $-15.68 \times$ RE.

The utilization efficiency of metabolizable protein for gain $(\mathrm{k})$ was calculated as proposed by Valadares Filho et al. (2010), in which : k (\%) = $84.665-\left(0.1179 \times{ }_{\text {eq }}\right.$ EBW $)$ for animals of body weight at fasting (BWF) lower or equal to $350 \mathrm{~kg}$ and a fixed value of 0.469 for animals above this weight.

Thus, the requirements of net and metabolizable energy for the maintenance of crossbred Holstein $\times$ Zebu bulls are of $78.7 \mathrm{kcal} / \mathrm{EBW}^{0.75} /$ day and $114.2 \mathrm{kcal} / \mathrm{EBW}^{0.75} /$ day, respectively. The net requirements for gain can be obtained through the equation: $\mathrm{NE}_{\mathrm{g}}=0.0493 \times \mathrm{EBW}^{0.75} \times \mathrm{EBWG}^{1.0013}$. The net requirements of protein for gain can be obtained through the equation $\mathrm{NP}_{\mathrm{g}}(\mathrm{g} /$ day $)=279.19$ $\times$ EBWG $-22.87 \times$ RE. The utilization efficiencies of metabolizable energy for deposition of protein $\left(\mathrm{k}_{\mathrm{p}}\right)$ and fat $\left(\mathrm{k}_{\mathrm{f}}\right)$ for finishing crossbred Holstein $\times$ Zebu bulls are of 0.2048 and 0.8848 , respectively.

\section{Acknowledgment}

The authors thank Fundação de Apoio à Pesquisa de Minas Gerais (FAPEMIG) for financing the research.

\section{References}

AGRICULTURALAND FOOD RESEARCH COUNCIL - AFRC. Energy and protein requirements of ruminants. Wallingford: CAB International, 1993. $159 \mathrm{p}$.

Agricultural Research Council - ARC. The nutrient requirements of ruminant livestock. London: Agricultural Research Council. The Gresham Press, 1980. 351 p.

CHIZZOTTI, M. L.; TEDESCHI, L. O.; VALADARES FILHO, S. C. A meta-analysis of energy and protein requirements for maintenance and growth of Nellore cattle. Journal of Animal Science. Savoy, v. 86, n. 3, p. 1588-1597, 2008.

COELHO DA SILVA, J. F.; LEÃO, M. I. Fundamentos de nutrição de ruminantes. Piracicaba: Livroceres, 1979. $380 \mathrm{p}$.

COSTA E SILVA, L. F. Exigências nutricionais, validação de equações para a estimação da composição do corpo vazio e uso da creatinina para estimar a proporção de tecido muscular em bovinos Nelore. 2011. Dissertação (Mestrado em Zootecnia) - Universidade Federal de Viçosa, Viçosa.

COMMONWEALTH SCIENTIFIC AND INDUSTRIAL RESEARCH ORGANIZATION - CSIRO. Nutrient Requirements of Domesticated Ruminants. Collingwood, VIC: Commonwealth Scientific and Industrial Research Organization, 2007. $270 \mathrm{p}$.

DETMANN, E.; VALADARES FILHO, S. C. On the estimation of non-fibrous carbohydrates in feeds and diets. Arquivos Brasileiro de Medicina Veterinária e Zootecnia, Belo Horizonte, v. 62, n. 4, p. 980-984, 2010.

FERRELL, C. L.; OLTJEN, J. W. ASA CENTENNIAL PAPER: net energy system for beef cattle - concepts, applications, and future models. Journal of Animal Science, Savoy, v. 86, n. 5, p. 2779-2794, 2008.

GARRETT, W. N. Factors influencing energetic efficiency of beef production. Journal of Animal Science, Savoy, v. 51, n. 12, p. 1434-1440, 1980. 
GIONBELLI, M. P. Desempenho produtivo e exigências nutricionais de fêmeas Nelore em crescimento. 2010. Dissertação (Mestrado em Zootecnia) - Universidade Federal de Viçosa, Viçosa, MG, 2010.

HANKINS, O. G.; HOWE, P. E. Estimation of the composition of beef carcasses and cuts. [T.B.]: United States Department of Agriculture, 1946. p.1-19 (Technical Bulletin - USDA, 926).

JOHNSON, D. E.; LARSON, E. M.; JAROSZ, M. J. Extrapoling from ME to NE: unintended consequences. In: PROCEEDINGS OF ENERGY METABOLISMO F FARM ANIMALS, 14., 1977, Newcastle. Anais... Newcastle: CAB International, 1977. p. 383-386.

MARCONDES, M. I.; PAULINO, P. V. R.; VALADARES FILHO, S. C.; GIONBELLI, M. P.; COSTA E SILVA, L. F.; TEDESCHI, L. O. Predição da composição corporal e da carcaça de animais Nelore puros e cruzados. In: VALADARES FILHO, S. C.; MARCONDES, M. I.; CHIZZOTTI, M. L.; PAULINO, P. V. R. Exigências nutricionais de zebuinos puros e cruzados (BR CORTE). 2. ed. Viçosa, MG: Suprema Gráfica LTDA, 2010. p. 6584.

MERTENS, D. R.; ALLEN, M.; CARMANY, J.; CLEGG, J.; DAVIDOWICZ, A.; DROUCHES, M.; FRANK, K.; GAMBIN, D.; GARKIE, M.; GILDEMEISTER, B.; JEFFRESS, D.; JEON, C. S.; JONES, D.; KAPLAN, D.; KIM, G. N.; KOBATA, S.; MAIN, D.; MOUA, X.; PAUL, B.; ROBERTSON, J.; TAYSON, D.; THIEX, N.; WILLIAMS, J.; WOLF, M. Gravimetric detergmination of amylase-treated neutral detergent fiber in feeds with refluxing in beakers or crucicles: Collaborative study. Journal of AOAC International, Maryland, v. 85, p. 1217-1240, 2002.

NATIONAL FORAGE TESTING ASSOCIATION. Laboratory dry matter by microwave drying to constant weight. Forage analyses procedures. 1993. Disponível em: <http://www.foragetesting.org/lab_procedure/labpro. pdf $>$. Acesso em: 01 mar. 2013.

NATIONAL RESEARCH COUNCIL - NRC. Nutrient requirements of beef cattle. 7. ed. Washington, D.C.: 2000. 242 p.
Nutrients requirements of dairy cattle. 7.ed. National Academic Press. Washington, D.C., 2001. 381 p.

SILVA, D. J.; QUEIROZ, A. C. Análise de alimentos: métodos químicos e biológicos. 3. ed. Viçosa: Imprensa Universitária; Universidade Federal de Viçosa, 2002. $165 \mathrm{p}$.

TEDESCHI, L. O.; BOIN, C.; FOX, D. G.; LEME, P. R.; ALLEONI, G. F.; LANNA, D. P. D. Energy requirements for maintenance and growth of Nellore bulls and steers fed high-forage diets. Journal of Animal Science, Savoy, v. 80, n. 6, p. 1671-1682, 2002.

TEDESCHI, L. O.; FOX, D. G.; GUIROY, P. J. A decision support system to improve individual cattle management. 1. A mechanistic, dynamic model for animal growth. Agricultural Systems, Maryland Heights, v. 79, n. 2, p. 171-204, 2004.

UNDERSANDER, D.; MERTENS, D. R.; THIEX, N. Forage analyses procedures. Omaha: National Forage Testing Association, 1993. 135 p. Disponível em: <http:// www.foragetesting.org/lab_procedure/labpro.pdf $>$. Acesso em: 01 fev. 2013.

VALADARES FILHO, S. C.; PAULINO, P. V. R.; MAGALHÃES, K. A. Exigências nutricionais de zebuinos e tabelas de composição de alimentos - BR CORTE. Viçosa : UFV, Suprema Gráfica Ltda, 2006, 142 p.

VALADARES FILHO, S. C.; MARCONDES, M. I.; CHIZZOTTI, M. L.; PAULINO, P. V. R. Exigências nutricionais de zebuinos puros e cruzados - BR CORTE. 2. ed. Viçosa : UFV, Suprema Gráfica Ltda, 2010. 193 p.

VALENTE, T. N. P.; DETMANN, E.; VALADARES FILHO, S. C.; QUEIROZ, A. C.; SAMPAIO, C. B.; GOMES, D. I. Avaliação dos teores de fibra em detergente neutro em forragens, concentrados e fezes bovinos moídas em diferentes tamanho e em sacos de diferentes tecidos. Revista Brasileira de Zootecnia, Viçosa, v. 40, n. 5, p. 1148-1154, 2011.

WILLIAMS, C. B.; JENKINS, T. G. A dinamic model of metabolizable energy utilization in growing and mature cattle. I. Model evaluation. Journal of Animal Science, Savoy, v. 81. n. 6, p. 1390-1398, 2003. 